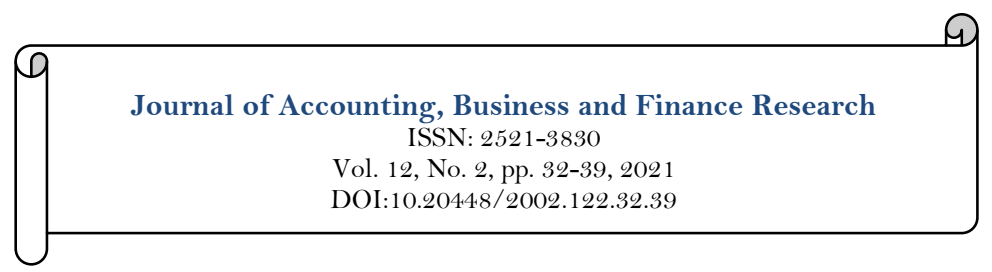

\title{
The Impact of Government Debt and Foreign Investment on the Indonesian Economy: An ARDL Model Analysis
}

\author{
Zainuddin IBA ${ }^{1 *}$ \\ Musrizal $^{2}$ \\ Lakharis INUZULA ${ }^{3}$ \\ Sutoyo $^{4}$
}

${ }_{1,3,4}$ Faculty of Economics and Business, Universitas Islam Kebangsaan Indonesia.

'Email: zaiba2882@gmail.com

${ }^{2}$ Faculty of Economics, Universitas Almuslim, Indonesia.

\begin{tabular}{|c|c|}
\hline Abstract & \\
\hline $\begin{array}{l}\text { This study aims to obtain empirical evidence of the effect of } \\
\text { government debt and foreign investment on Indonesia's economic } \\
\text { growth. A number of macroeconomic variables are used to explain } \\
\text { the influence between variables in both the short and long terms. } \\
\text { The short-term effect is explained through the autoregressive } \\
\text { distributed lag (ARDL) model, while the long-term effect is } \\
\text { explained through the long-run bounds test. The ARDL model } \\
\text { shows that government debt, inflation, exchange rates and the BI } \\
\text { rate have a negative and significant effect on economic growth. } \\
\text { Meanwhile, foreign investment has a positive and significant effect } \\
\text { on economic growth. The results of the long-run bounds test show } \\
\text { that the increase in government debt and foreign investment does } \\
\text { not have a significant effect on economic growth. Meanwhile, } \\
\text { inflation and exchange rates have a negative and significant effect on } \\
\text { economic growth. This is contrary to the case with the BI rate, } \\
\text { which has a positive and significant impact on economic growth. The } \\
\text { increase in government debt in the long term has an impact on the } \\
\text { decline in output and public consumption. This is the impact of an } \\
\text { increase in the tax burden in the future. }\end{array}$ & $\begin{array}{l}\text { Keywords: } \\
\text { Government debt } \\
\text { Foreign investment } \\
\text { Macroeconomics } \\
\text { Economic growth. } \\
\text { JEL Classification: } \\
\text { E6; E62; F2; F63. } \\
\text { Licensed: } \\
\text { This work is licensed under a } \\
\text { Creative Commons Attribution } 4.0 \\
\text { License. } \\
\text { Publisher: } \\
\text { Scientific Publishing Institute } \\
\text { Received: } 12 \text { May } 2021 \\
\text { Revised: } 16 \text { June } 2021 \\
\text { Accepted: } 7 \text { July } 2021 \\
\text { Published: } 4 \text { August } 2021 \\
\text { ( Corresponding Author) }\end{array}$ \\
\hline
\end{tabular}

Funding: This study received no specific financial support.

Competing Interests: The authors declare that they have no competing interests.

\section{Introduction}

This study aims to obtain empirical evidence related to the effect of government debt, foreign investment and macroeconomic variables on Indonesia's economic growth. The ARDL analysis model is used to identify the effect of the independent variable on the dependent variable. In conditions of a fiscal deficit, an increase in government spending has the potential for fiscal risk, which is the risk caused by an excessive increase in debt. The increase in government debt is in line with the increasing need for the government to finance expenditures. Currently, government spending is mainly aimed at reducing the impact of Covid-19 on the economy. In 2020, the fiscal deficit exceeded the maximum limit of $3 \%$ of GDP. This limit was regulated in Law No. 17 of 2003 concerning state finance. The increase in the deficit also stems from changes in macroeconomic assumptions that are difficult to predict as a result of global economic pressures. The increase in government spending has had an adverse effect on increasing the deficit, increasing government debt and 
slowing down the economy. This also puts strong pressure on a number of macroeconomic variables, such as inflation, the State Bank of India (SBI), and exchange rates.

According to Ricardian understanding, fiscal deficits financed by debt will not have an effect on improving the economy. This is because the long-term government debt is paid through an increase in the tax burden imposed on the community.

An increase in the tax burden results in a decrease in public consumption. A number of studies have stated that an increase in government debt is closely related to an increase in the fiscal deficit. The increase in the deficit is in line with the increasing need for the government to finance development. In the short term, spending affects economic growth. This is in line with the study conducted by (Hazmi, Faisal, \& Cahyani, 2019). Fiscal deficit has a positive and significant effect on government debt, and the increase in debt has a positive and significant impact on Indonesia's economic growth. In the long term, the increase in debt is not significant to Indonesia's economic growth.

In a deficit condition, the government tends to increase debt. Ideally, this effort is only carried out in the short term. In the long run, an increase in debt will create an accumulation of government debt, and the accumulation of debt tends to damage the economic structure and economic sustainability, and create greater distortions, so that it has an impact on increasing the tax burden. The study by Hazmi et al. (2019) found a positive interaction between debt accumulation and fiscal deficit. Excessive accumulation of debt tends to worsen the economy. Fiscal deficits financed through debt tend to be less productive and causes economic growth to decline. This requires a maximum debt limit.

The endogenous growth model states that there is an important role for investment in economic growth. Economic growth has an effect on increasing aggregate production and tends to encourage investment to grow. Investment encourages increased resources and creates positive externalities to the economy and spurs increased productivity. This model also places importance on role of technology in increasing growth. When economic factors are at their maximum point, an increase in output can only happen through technological improvements.

The endogenous growth model states that technology is an important factor in the creation of long-term economic growth. In addition to the technological factor, this model also emphasizes the existence of investment. An increase in investment will increase aggregate demand, national income and employment opportunities. It will also encourage consumption to increase, which in turn increases income. The relationship between investment and national income has been explained by Keynes. A number of studies mention that the increase in government debt, investment, and macro variables affect economic growth. Dwi and Muhammad (2016) stated that there is a one-way relationship between government debt, investment and economic growth in Indonesia.

Foreign debt has a positive effect on GDP growth, while investment has a negative effect. Syahrini et al. (2021) stated that investment has a positive and significant effect on economic growth in Indonesia. Kasidi and Said (2013) found that government debt has a positive and significant effect on economic growth. In another study, debt was found to have a negative effect on the economic growth of a country. This result is in line with the study by Hayat, Hayat, and Malik (2010), who found that foreign debt has a negative effect on Pakistan's economic growth.

In a study by Ajayi and Oke (2012), foreign debt was found to have a negative effect on Nigeria's economic growth, which is caused by currency devaluation so that the Nigerian economy is depressed. Amid the fiscal deficit and increasing debt, the government tends to use expansionary fiscal policy as a fiscal instrument in economic growth. This policy is appropriate to use in times of economic recession. Because Indonesia was affected by Covid-19, maintaining this policy is not the right course of action. An increase in government spending tends to increase the formation of excessive debt accumulation and fiscal risk.

\section{Literature Review}

\subsection{Fiscal Deficit and Economic Growth}

Economic growth shows an increase in the long-term output of a country's goods and services. The increase in output is closely related to the technological, institutional and ideological levels. Economic growth is closely related to the amount of government spending. When government spending is greater than revenue, fiscal deficit will occur.

In a deficit condition, the government in the short term tends to draw new debt to cover the fiscal deficit. In addition to withdrawing debt, it also imposes a greater tax burden on the community. An increase in taxes can cause disposable income to decrease, so consumption and output also experience a decline. In the short run, deficits tend to increase demand, thereby driving higher output.

Fiscal policy can increase aggregate demand. However, without being accompanied by an accommodative monetary policy in the long term, this will be counterproductive. Expansive fiscal policy tends to cause debt to increase and so does inflation. In the long term, debt affects the amount of tax that must be paid by the public, so that economic growth slows down. Prolonged fiscal deficit adversely affects fiscal performance and brings macroeconomic instability. A number of studies state that fiscal deficit has an effect on economic growth. This is in line with Dwinanda and Berly (2015) and Khairul (2014). However, the results of this study state that the 
fiscal deficit has a positive and significant effect on debt in Indonesia. This is because the government tends to use debt to finance development.

\subsection{Government Debt on Economic Growth}

Keynesian ideology states that the increase in spending originating from foreign debt has a positive effect on economic growth. The increase in debt has an effect on aggregate demand originating from capital accumulation. Fiscal deficit covered by foreign debt results in increased public income and consumption. However, the Ricardian point of view is that using foreign debt to finance the deficit has a negative effect on economic growth. An increase in spending results in debt, and this will reduce consumption in the future. As a result, the government imposes higher taxes.

A number of studies explain the effect of debt on economic growth. Dison and Nyoman (2015) found that government debt has a negative effect on GDP growth in Indonesia. This result is in line with the studies by Syahrini et al. (2021) and Hazmi, Masbar, Nazamuddin, and Abdullah (2019), who stated that government debt has a negative effect on Indonesia's economic growth. Withdrawal of debt to finance the deficit in the long term has the potential to create excessive debt accumulation and fiscal risk. This requires setting a maximum amount of debt.

Debt growth every year without being accompanied by income growth brings economic decline as more debt is accrued to pay old debts that have matured. Foreign debt can increase employment opportunities and increase consumption, thus affecting GDP growth. In the short term, foreign debt plays a role in reducing the fiscal deficit. However, in the long term, foreign debt causes the rupiah to weaken (Atmadja, 2000).

\subsection{Investment in Economic Growth}

Neoclassicism states that expansionary policies in conditions of a fiscal deficit tend to have a negative effect on economic growth. This is the impact of lowering investment, especially if the fiscal deficit continues to increase. Deficit policy by lowering tax rates will increase interest rates and reduce investment. This results in a decline in economic growth. Expansive policy as a fiscal instrument, under certain conditions, is inappropriate and tends to cause inflation to increase and interest rates to rise. This results in expensive investment and slows economic growth. The main problem of investment today is to maximize the role of investment in economic growth.

Government policies related to investment have not had an effect on the rate of investment growth. The Harrod-Domar and Solow-Swan theories of economic growth state that investment tends to affect the acceleration of economic growth. A number of studies state that investment is closely related to economic growth, and this is in line with the study by Jilenga and Xu (2016) in Tanzania. In their research, long-term investment tends to encourage economic growth. Ulfa and Zulham (2017) mentions that investment has a positive and significant impact on Indonesia's economic growth, and the study by Klolis (2012) states that foreign investment has a significant positive effect on economic growth in Indonesia. Thus, increased investment will lead to economic growth. Putri (2014) concluded that increasing investment has an impact on economic growth through an increase in infrastructure, and improved infrastructure has a multiplier effect on production and increases employment opportunities and income.

However, a number of studies have stated that foreign investment has a negative effect on economic growth. This is in line with the study by Nizar, Hamzah, and Syahnur (2013), who stated that foreign investment has no effect on economic growth in Indonesia. Increase investment has no effect on the increase in national income.

\subsection{Macroeconomics on Economic Growth}

According to monetarists, inflation occurs due to an excess supply of money in the community, resulting in a decrease in the purchasing power of money. However, monetarism has been criticized by non-monetarists. Non-monetary experts believe that inflation occurs as a result of excess aggregate demand, which stems from increases in consumption, investment, government spending and net exports. Thus, inflation is caused by monetary and non-monetary factors. From an economic perspective, inflation is a monetary phenomenon and tends to affect the dynamics of economic growth. The inflation rate affects the cost of producing goods and services, and inflation is one of the macroeconomic indicators used to measure the stability of a country's economy.

Changes in the inflation rate have an impact on the dynamics of economic growth. The relationship between inflation and economic growth shows a negative effect (Syahrini et al., 2021). High inflation slows economic growth in a region, so government intervention is needed to control the inflation rate at a low level. A number of studies posit that inflation has a negative effect on economic growth and that inflation is negatively and significantly related to economic growth in Indonesia. The same results were found by Royda and Agung (2018), who state that inflation results in high production costs and an increase in unemployment, thus disrupting the economy.

In addition to inflation, the exchange rate, which is sourced from international trade (exports and imports), also has an influence on economic growth. Countries with smaller exports compared to imports will 
experience a trade balance deficit and exchange rate depreciation. Exchange rate affects economic growth through people's purchasing power. A decline in domestic production increases the import of goods and services, and the increase in imports results in an increase in the demand for foreign exchange. This will weaken the domestic exchange rate against foreign currencies. Pratiwi (2015) concluded that the exchange rate has a positive and significant effect on Indonesian economic growth, with the strengthening of the exchange rate causing the purchasing power of money to increase.

\section{Methodology}

\subsection{Data Analysis Model}

This study uses secondary time series data, requiring a unit root test. This test is performed using the augmented Dickey-Fuller (ADF) test for each variable. The ADF test formulation is as follows:

$$
\Delta \mathrm{y}_{\mathrm{t}}=\mu+\mathrm{yy}_{\mathrm{t}-1}+\varepsilon_{\mathrm{t}}
$$

The hypotheses to be tested are:

$\mathrm{H}_{\mathrm{O}: \mathrm{y}}-\mathrm{O}$

$\mathrm{H}_{0}: \mathrm{y}<\mathrm{O}$

If the null hypothesis is accepted, it means that the series is not stationary, in other words, it contains a unit root.

The augmented Dickey-Fuller test is a development of the Dickey-Fuller test. The ADF test uses correction parameters for higher order correlations by assuming that the y series follows the AR (p) process and makes adjustments to the test method. The ADF approach also controls for higher order correlations by adding the lag of the difference term for the dependent variable y to the regression equation as referred to in (2) below:

$\Delta \mathrm{y}_{\mathrm{t}}=\mu+\mathrm{yy}_{\mathrm{t}-1}+\delta_{1} \Delta \mathrm{y}_{\mathrm{t}-1}+\delta_{2} \Delta \mathrm{y}_{\mathrm{t}-2}+\ldots+\delta_{\mathrm{p}-1} \Delta \mathrm{y}_{\mathrm{t}-\mathrm{p}-1}+\delta_{\mathrm{p}} \Delta \mathrm{y}_{\mathrm{t}-\mathrm{p}}+\varepsilon_{\mathrm{t}}$

The augmented specification is then used to test:

$$
\begin{aligned}
& \mathrm{H}_{\mathrm{O}}: \mathrm{y}=\mathrm{O} \\
& \mathrm{H}_{1}: \mathrm{y}<\mathrm{O}
\end{aligned}
$$

Furthermore, the determination of the optimum lag is carried out. This is done by using the Akaike Information Criterion (AIC) basis value approach, so that the smallest criterion value can be determined. The next step is to perform a cointegration test using the following equation:

$$
\mathrm{y}_{\mathrm{t}}=\beta_{\mathrm{o}}+\beta_{1} \mathrm{X}_{1}+\varepsilon_{\mathrm{t}}
$$

So, the variance of the equation becomes:

Where:

$$
\varepsilon_{\mathrm{t}}=\mathrm{y}_{\mathrm{t}}-\beta_{0} \mathrm{X}_{0}-\beta_{1} \mathrm{X}_{1}
$$

$\mathrm{t}$ is a linear combination of $\mathrm{X}_{1}$ and $\mathrm{X}_{2}$. The cointegration concept requires $\mathrm{t}$ to be stationary at $\mathrm{I}(\mathrm{O})$ in order to produce long-run equilibrium.

\subsection{ARDL Estimation Model}

The ARDL estimation model is a combination of the autoregressive model with distributed lag. The autoregressive (AR) model uses one or more past data from the variable $Y$. Meanwhile, the distributed lag (DL) is a regression model that involves present and past data from the variable $X$. The ARDL estimation formulation is:

$$
y_{t}=\alpha_{0}+\alpha_{1} t+\sum_{\mathrm{i}=1}^{\mathrm{p}} \emptyset_{i} y_{t-1}+\hat{\mathrm{a}}^{\prime} x_{t} x_{t}+\sum_{\mathrm{i}=0}^{\mathrm{q}-1} \beta \mathrm{j} * \Delta x_{t-j}+\mathrm{\eta}_{t}
$$

Where $\mathrm{m}=\operatorname{maximum}(\mathrm{q}, \mathrm{s}=1), \pi_{1}=1 \bullet-\mathrm{P}_{1}{ }^{\prime} \mathrm{d}$, where $1 \mathrm{x} 1$ is the vector containing the contemporary correlation between $\mathrm{u}_{\mathrm{t}}$ and $\varepsilon_{\mathrm{t}}$, so the ARDL approach requires the inclusion of a sufficient lag of the forcing variable $\mathrm{x}_{\mathrm{t}}$ in order to homogenize $\mathrm{y}_{\mathrm{t}}$. By doing this, endogenous regression problems and serial autocorrelation can be corrected simultaneously.

Where:

$$
\Delta x_{t}=P_{1} \Delta x_{t-1}+P_{2} \Delta x_{t-2}+\ldots+P_{s} \Delta x_{t-S}+\varepsilon_{t}
$$

$x=$ the variable with dimension $\mathrm{k}$ at integration $1(1)$, not cointegrated between them.

$\mathrm{T}=$ error with zero mean, constant variance and covariance, and no serial correlation.

$\mathrm{P}_{\mathrm{t}}=$ coefficient matrix $\mathrm{k} \mathrm{x}$ vector autoregressive process at stable $\mathrm{x}_{\mathrm{t}}$.

The ARDL estimates explain the equilibrium relationship in the short run. The ARDL approach requires a lag, which indicates the time it takes to respond $(\mathrm{Y})$ as a result of an effect. Lag selection is done using the Akaike Information Criteria (AIC). The ARDL model also requires negative and significant ECT values as a measure of long-term parameter stability. Meanwhile, to determine the effect in the long term, the long-run bounds test was carried out. 


\subsection{Research Formulation}

The formulation of the ARDL model in this study is:

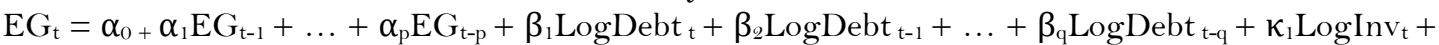
$\kappa_{2} \log _{\operatorname{Inv}} \mathrm{t}_{-1}+\ldots+\kappa_{\mathrm{q}}{\log I n v_{\mathrm{t}-\mathrm{q}}}+\gamma_{1} \operatorname{Inf}_{\mathrm{t}}+\gamma_{2} \operatorname{Inf}_{\mathrm{t}-1}+\ldots+\gamma_{\mathrm{r}} \operatorname{Inf}_{\mathrm{t}-\mathrm{r}}+\rho_{1} \operatorname{LogER}_{\mathrm{t}}+\rho_{2} \operatorname{LogER}_{\mathrm{t}-1}+\ldots+\rho_{\mathrm{s}} \operatorname{LogER}_{\mathrm{t}-\mathrm{s}}+$

$\mathrm{q}_{1} \mathrm{BIR}_{\mathrm{t}}+\mathrm{q}_{2} \mathrm{BIR}_{\mathrm{t}-1}+\ldots+\mathrm{q}_{\mathrm{t}} \mathrm{BIR} \mathrm{t}-\mathrm{t}+\varepsilon_{\mathrm{t}}$

Where:

$\mathrm{EG}_{\mathrm{t}}=$ economic growth at time $\mathrm{t}$.

$\mathrm{EG}_{\mathrm{t}-1}=$ economic growth at time $\mathrm{t}-1$.

$\operatorname{LogDebt}_{\mathrm{t}-1}=$ government debt $\log$ at time $\mathrm{t}-1$.

$\log \operatorname{Inv}_{\mathrm{t}-1}=$ foreign investment $\log$ at time $\mathrm{t}-1$.

$\mathrm{Inf}_{\mathrm{t}-1}=$ inflation at time $\mathrm{t}-1$.

$\operatorname{LogER} \mathrm{R}_{\mathrm{t}-1}=\log$ exchange rate at time $\mathrm{t}-1$.

$\mathrm{BIR}_{\mathrm{t}-1}=\mathrm{BI}$ interest rate at time $\mathrm{t}-1$.

$\mathrm{t}=$ error term.

\section{Survey Results and Descriptive Statistics}

\subsection{Data Stationarity}

The results of the ADF unit root test show that the variables of economic growth (EG), inflation (Inf), exchange rate $(\mathrm{ER})$ and Bank Indonesia rate $(\mathrm{BIR})$ are stationary at $\mathrm{I}(\mathrm{O})$, while government debt (Debt) and foreign investment (Inv) are stationary at I(1). From the results of the data stationary test, the selection of the ARDL analysis model has been fulfilled. The ARDL model is one of the appropriate models to be used in achieving the research objectives, mainly related to the influence of the independent variable on the dependent variable, both in the short and long terms. The results of the unit root test are shown in Table 1, with a confidence level equal to $5 \%$.

Table 1. ADF unit root test results.

\begin{tabular}{c|c|c|c}
\hline \multirow{2}{*}{ Variable } & t-stats & MacKinnon critical & \multirow{2}{*}{ Information } \\
\cline { 2 - 3 } & ADF & Value $\mathbf{( 5 \% )}$ & \\
\hline EG & -17.27413 & -4.443649 & Stationary at I $(0)$ \\
\hline Debt & -5.095085 & -4.859812 & Stationary at $\mathrm{I}(\mathbf{1})$ \\
\hline Inv & -5.799008 & -4.443649 & Stationary at $\mathrm{I}(1)$ \\
\hline Inf & $-14,42315$ & -4.443649 & Stationary at I $(0)$ \\
\hline ER & -5.649960 & -4.443649 & Stationary at I $(0)$ \\
\hline BIR & -5.391481 & -4.443649 & Stationary at I $(0)$ \\
\hline
\end{tabular}

\subsection{Model Stability Test}

To maximize the results from the time series data, it is necessary to test the stability of the model. The stability test is carried out is using Cusum and CusumQ tests, with a confidence level of 95\%. The results of the model stability test are shown in Figure 1 and Figure 2.

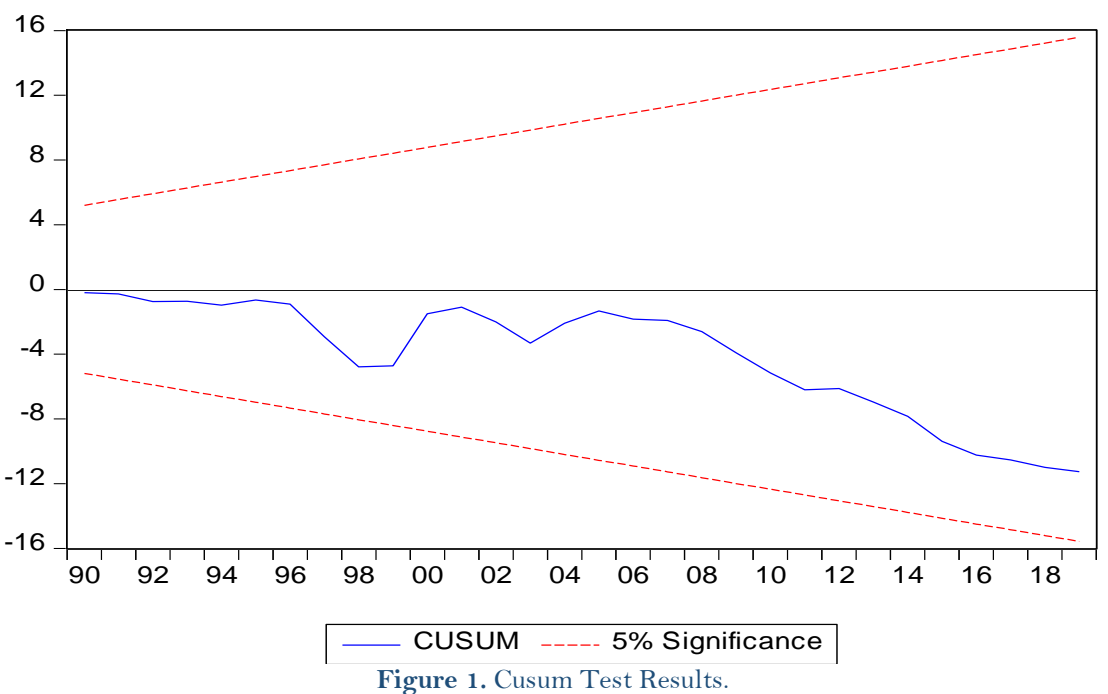


The Cusum model stability test proves that the data used in this study is stable based on the results which place the position of the Cusum line (blue) between two positive and negative significance lines (red) at $\alpha$ equal to $5 \%$.

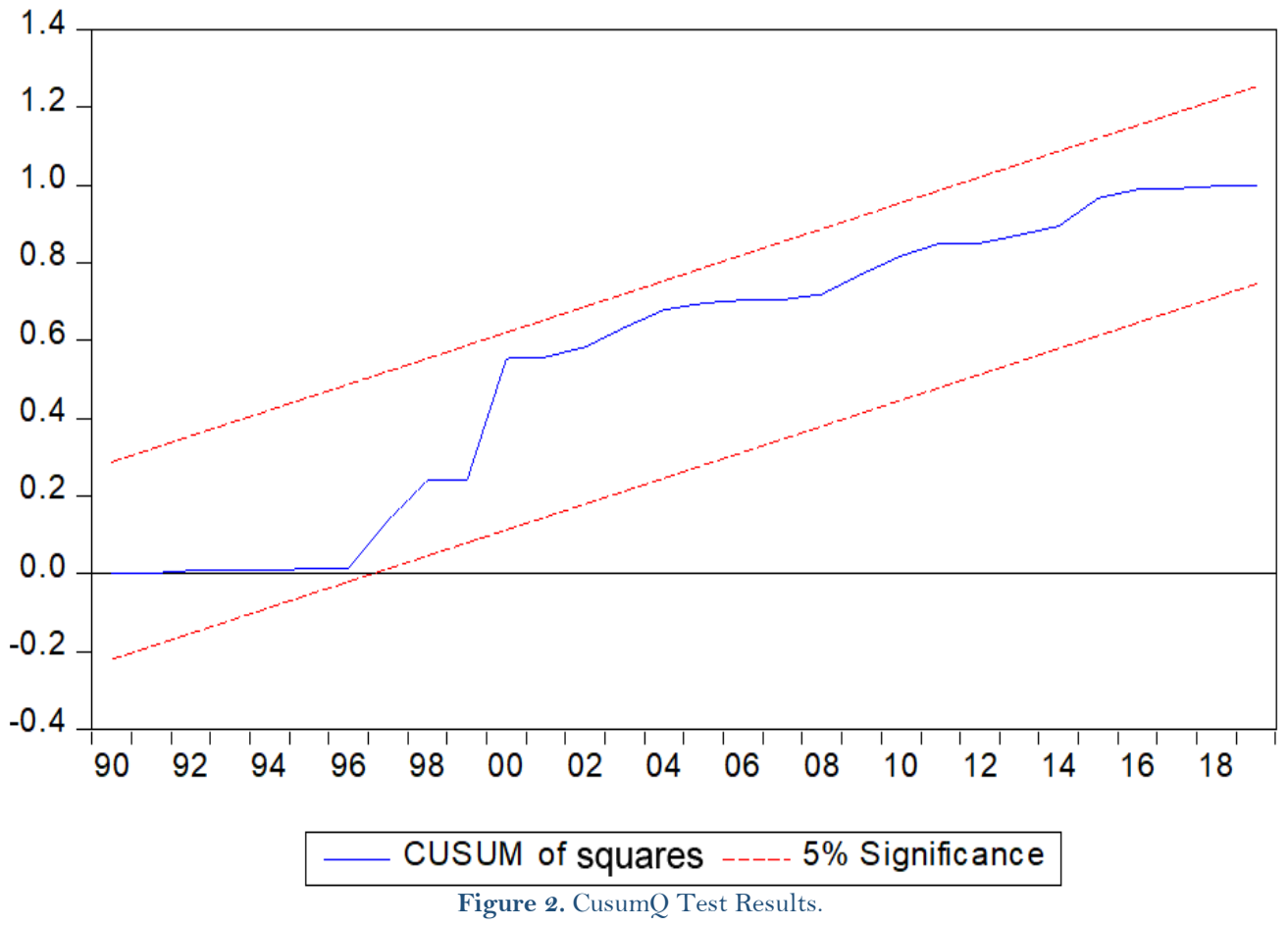

Furthermore, the results of the CusumQ model stability test in Figure 2 prove that the model is stable. This can be seen from the position of the CusumQ line (blue), which is between the two positive and negative significance lines (red) at $\alpha$ equal to $5 \%$.

\subsection{Long-run Bounds Cointegration Test}

From the results of the long-run bounds test, as shown in Table 2, long-term government debt and investment do not have a significant effect on economic growth. Meanwhile, the macroeconomic variables consisting of inflation, exchange rate and BIR have a significant effect in the long term.

Table 2. Long-run bounds test results.

\begin{tabular}{c|c|c|c|c}
\hline Variable & Coefficient & Std. error & t-statistic & Prob. \\
\hline Debt & 0.003627 & 0.001050 & $3,453,645$ & 0.1790 \\
\hline Inv & 0.083753 & 0.135829 & 0.616604 & 0.6482 \\
\hline Inf & -0.412209 & 0.099750 & $-4,132.409$ & 0.0151 \\
\hline ER & -0.409370 & 0.101020 & $-4,052,374$ & 0.0154 \\
\hline BIR & 0.350071 & 0.132406 & $2,643,921$ & 0.0230 \\
\hline C & $4,989,997$ & $1,735,148$ & $2,875,834$ & 0.2130 \\
\hline
\end{tabular}

In the long term, inflation and exchange rates have a positive and significant effect on economic growth. Meanwhile, BIR has a negative and significant effect. Government debt and investment in the long term have no effect on economic growth. An increase in debt does not result in an increase or decrease in economic growth. However, a number of studies conclude that debt in the long term has an effect on economic growth.

\subsection{ARDL Model: Short-run Estimation}

The estimation results of the ARDL method, shown in Table 3, prove that the independent variable has an effect on the dependent variable. In the short term, government debt is at lag -1 and current investment has an effect and is significant on economic growth in Indonesia. This happened through the macro variables of inflation, exchange rates and BIR. 
Table 3. ARDL model test results.

\begin{tabular}{c|c|c|c|c}
\hline Variable & Coefficient & Std. error & t-statistic & Prob. $^{*}$ \\
\hline EG(-1) & 0.235472 & 0.104737 & $2,248,208$ & 0.0344 \\
\hline EG(-2) & -0.102032 & 0.074424 & $-1,370,956$ & 0.1836 \\
\hline Debt & -0.001734 & 0.001398 & $1,240,727$ & 0.0272 \\
\hline Debt $(-1)$ & -0.002168 & 0.001613 & $-1,344,091$ & 0.0192 \\
\hline Inv & 0.186422 & 0.219873 & 0.847862 & 0.0453 \\
\hline Inf & -0.188427 & 0.035753 & $-5,270,227$ & 0.0000 \\
\hline ER & -0.236246 & 0.107902 & $-2,189,451$ & 0.0390 \\
\hline BIR & -0.083094 & 0.063352 & $-1,311,623$ & 0.0226 \\
\hline BIR(-1) & -0.034080 & 0.064165 & -0.531123 & 0.0304 \\
\hline C & $9,670,440$ & $1,754,190$ & $5,512,766$ & 0.0000 \\
\hline
\end{tabular}

The results of testing the ARDL analysis model show that all independent variables (government debt, foreign investment, inflation, exchange rates and BI rate) have a balance effect in the short term on the dependent variable (economic growth). Government debt, inflation, exchange rate and BI rate have a negative and significant effect on economic growth. Meanwhile, foreign investment has a positive and significant effect on economic growth.

\section{Discussion}

Withdrawal of new debt to finance the fiscal deficit in the long term tends to have a negative effect on economic growth and a number of macroeconomic variables, such as inflation, exchange rates, and BI rate. Debt withdrawal has an effect on increasing inflation through the money supply. Likewise, with respect to the exchange rate, the increase in debt has led to the weakening of the rupiah against foreign currencies (depreciation). The addition of debt in a state of deficit only increases the tax burden on the community. The government uses tax instruments to increase state revenues. This is also a form of the government's failure to increase state revenue, especially from non-tax sources. The tax instrument is the government's preferred method of increasing state revenues. However, this policy has had a negative impact on the growth of output and public consumption. Increased debt also affects the amount of money circulating in the community, thereby encouraging an increase in inflation.

The impact of the increase in debt is an increase in the BI rate, which is related to the policy of the Bank Indonesia to control inflation, and it has an effect on the investment costs. In this condition, investment will decrease. In several studies, investment was shown to have an effect on economic growth. However, this study finds that foreign investment in the long term has no significant effect on Indonesia's economic growth. This is illustrated by the estimation results of the long-run bounds test model. Even though the results are different (in the short term), policies related to investment (domestic and international) are needed. This is intended to reduce the government's dependence on debt, especially in an effort to increase economic growth. Government debt in the short term affects the increase in economic growth, and the increase in debt in the long term has no effect on economic growth. Ideally, debt withdrawal should not be carried out continuously, and a maximum limit on the amount of debt is required. Debt that exceeds the maximum limit tends to cause a number of problems, including a decrease in output and public consumption as a result of an increase in the tax burden. To overcome this, policies related to debt are needed, such as a maximum limit of money and the use of debt. Ideally debt is only intended for economic sectors that have an impact on growth.

\section{References}

Ajayi, L. B., \& Oke, M. O. (2012). Effect of external debt on economic growth and development of Nigeria. International Journal of Business and Social Science, 3(12), 297-304.

Atmadja, A. (2000). Indonesian government external debt: Development and impact. Journal of Accounting and Finance, 2(1), 83-94.

Dison, M. C., \& Nyoman, I. (2015). Analysis of the relationship of exports, imports, GDP and Indonesia's external debt, 1970-2013. Journal of Applied Quantitative Economics, $8(1), \quad 1-12$. https://doi.org/10.24843/JEKT.2015.v08.iO1.p05

Dwi, S., \& Muhammad, S. W. S. (2016). Economic growth, human development index, external debt and poverty (Theoretical Study in Indonesia). Journal of Innovation in Business and Economics, 6(1), 2276. https://doi.org/10.22219/jibe.v6i 1.2276

Dwinanda, A. S., \& Berly, M. (2015). Effect of fiscal deficit on economic growth in Indonesia, period 1990-2012. Indonesian Journal of Economics and Development, 15(2), 538. https://doi.org/10.21002/jepi.v15i2.538

Hayat, M., Hayat, M., \& Malik, S. (2010). External debt and economic growth: Empirical evidence from Pakistan. International Research Journal of Finance and Economics, 44(July), 95-104. https://doi.org/10.1108/jeas-12-20140035 
Hazmi, Y., Faisal, P. Y., \& Cahyani, I. (2019). Government debt accumulation, subsidies and fiscal sustainability in Indonesia. Paper presented at the Journal of the Proceedings of the Lhokseumawe State Polytechnic National Seminar.

Hazmi, Y., Masbar, R., Nazamuddin, \& Abdullah, S. (2019). Analysis of subsidies, inflation, exchange rates, BI rates on fiscal sustainability in Indonesia. Journal of Social Sciences and Economic Research, 4(3), 2049-2079.

Jilenga, M., \& Xu, D. (2016). The impact of external debt and foreign direct investment on economic growth: Empirical evidence from Tanzania. International Journal of Financial Research, 7(2), 154 doi: http://dx.doi.org/10.5430/ijfr.v7n2p154

Kasidi, F., \& Said, A. M. (2013). Impact of external debt on economic growth: A case study of Tanzania. Advances in Management and Applied Economics, 3(4), 1-6.

Khairul, A. (2014). Analysis of economic growth and income inequality: Panel data on 8 provinces in sumatra. Our Journal of EMT, 1(2), 588-603.

Klolis, M. (2012). Impact of foreign direct investment on indonesia's economic growth; Macroeconomic studies with the application of panel data. Journal of Organization and Management, 8(2), 111-120.

Nizar, C., Hamzah, A., \& Syahnur, S. (2013). The effect of investment and labor on economic growth, and their relationship to poverty levels in Indonesia. Journal of Economics, 1(2), 1-8.

Pratiwi, N. M. (2015). The influence of inflation, SBI interest rates, and exchange rates on foreign investment and economic growth in Indonesia (2004-2013). Journal of Business Administration, 26(2), 1-9.

Putri, P. I. (2014). Effect of investment, labor, capital expenditure, and infrastructure on economic growth in Java. Journal of Economics and Policy, 7(2), 100-202.

Royda, \& Agung, A. S. (2018). The effect of wages on productivity and inflation in the manufacturing industry sector in Palembang City Scientific Journal of Global Economics, 9(1), 15-20. https://doi.org/10.36982/jiegmk.v9i 1.443

Syahrini, I., Raja, M., Aliasuddin, M. S., \& Hazmi, Y. (2021). The application of optimal control through fiscal policy on indonesian economy. Journal of Asian Finance, Economics and Business, 8(3), 741-750.

Ulfa, S., \& Zulham, T. (2017). Analysis of foreign debt and economic growth: A study of the influencing factors. EKP Student Scientific Journal, 2(1), 144-152. 